\title{
Sensitive Anticancer Agent
}

National Cancer Institute

\section{Source}

National Cancer Institute. Sensitive Anticancer Agent. NCI Thesaurus. Code C128238.

An FDA-approved anticancer agent that an $\mathrm{NCl}-60$ cell line is predicted to be sensitive to. 